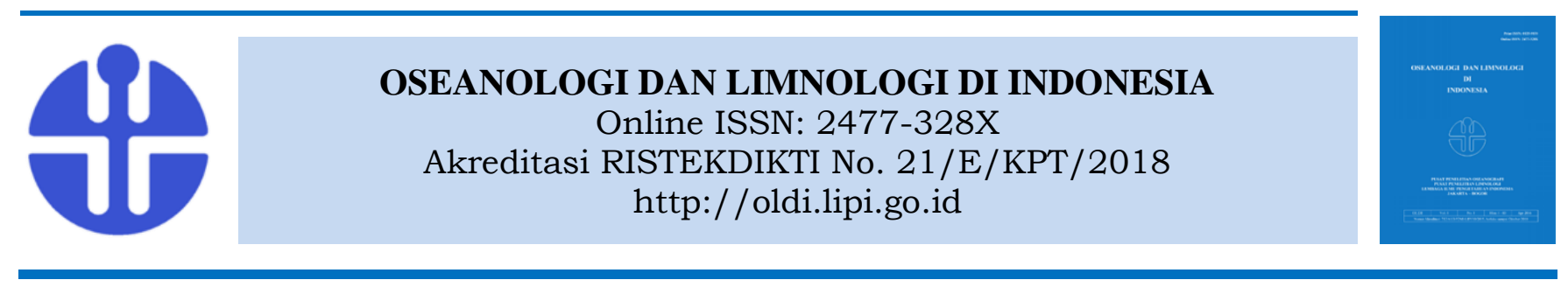

\title{
Akumulasi Logam Berat Pada Kerang Hijau di Perairan Pesisir Jawa
}

\author{
Ariani Andayani ${ }^{1)}$, Isti Koesharyani ${ }^{1)}$, Ulfa Fayumi ${ }^{1)}$, Rasidi ${ }^{1)}$, dan Ketut Sugama ${ }^{1)}$ \\ ${ }^{1}$ Pusat Riset Perikanan, Jakarta. \\ Gedung BRSDMKP II, Jl. Pasir Putih II, Ancol Timur, Jakarta, Indonesia \\ E-mail: arianiandayani@gmail.com
}

Submitted 16 July 2019. Reviewed 17 July 2020. Accepted 5 August 2020.

DOI: 10.14203/oldi.2020.v5i2.279

\begin{abstract}
Abstrak
Kerang hijau, Perna viridis di beberapa negara dimanfaatkan sebagai bahan pangan. Selain itu kerang hijau juga sering digunakan sebagai indikator pencemaran bahan organik yang bersifat toksik di suatu perairan karena kerang hijau hidup secara sesil sehingga dapat mengakumulasi bahan toksik seperti logam berat. Di Indonesia kerang hijau banyak dibudidayakan di perairan pantai utara Pulau Jawa. Pulau Jawa merupakan pusat ekonomi juga memiliki penduduk yang padat dan banyak kawasan industri. Seluruh aktivitas penduduk dan industri kerap kali menghasilkan limbah yang terbuang ke sungai dan tanpa pengolahan yang efisien akan terbawa aliran sungai ke laut dan menyebabkan pencemaran. Tujuan dari penelitian ini adalah untuk mengukur akumulasi logam berat seperti $\mathrm{Hg}, \mathrm{Cd}, \mathrm{Pb}$ yang terdapat pada tubuh kerang hijau. Sampel kerang hijau diambil pada tahun 2017, dari satu stasiun (pengepul) di empat lokasi yang berdekatan dengan lokasi budidaya di pesisir Jawa yaitu dari perairan pantai Panimbang, Teluk Jakarta, Brebes, dan Cirebon. Hasil analisa kandungan logam berat $\mathrm{Hg}$, $\mathrm{Pb}$, dan $\mathrm{Cd}$ di empat lokasi sebagai berikut: Panimbang berkisar dari tidak terdeteksi hingga $<0,22 \mathrm{mg} / \mathrm{kg}$, Teluk Jakarta berkisar dari $0,42 \mathrm{mg} / \mathrm{kg}$ hingga $29,4 \mathrm{mg} / \mathrm{kg}$, Brebes $0,01 \mathrm{mg} / \mathrm{kg}$ hingga 3,52 mg/kg, dan Cirebon 0,01 mg/kg hingga 2,66 mg/kg. Hasil tersebut menunjukan bahwa hanya kerang hijau yang berasal dari Panimbang mempunyai kandungan logam berat dibawah ambang batas yang diijinkan untuk dikonsumsi oleh manusia.
\end{abstract}

Kata Kunci: kerang hijau, logam berat, pesisir Jawa.

\begin{abstract}
Heavy Metal Accumulation on Green Mussels in the Java Coastal Water. In many countries, green mussel (Perna viridis) is harvested as food source. It is also commonly used as indicators for toxic contaminant, i.e. heavy metals, in the coastal waters. In Indonesia, green mussels are mostly cultivated in the north coast of Java where most industrial estates are located. Without further treatment, toxic contaminant of industrial waste may give impact to the surrounding environment, not to mention the adjacent coastal waters. This study was aimed to determine the accumulation of heavy metals, namely $\mathrm{Hg}, \mathrm{Pb}$ and $\mathrm{Cd}$, in green mussels. Green mussel samples were collected in 2017, taken from four culture sites in the north coast of Java: Panimbang, Jakarta Bay, Brebes and Cirebon. Our results showed that the concentration of $\mathrm{Hg}, \mathrm{Pb}$ and $\mathrm{Cd}$ in green mussel tissues of
\end{abstract}


those locations are: Panimbang = Hg: $<0.22 \mathrm{mg} / \mathrm{kg}, \mathrm{Pb}$ : undetectable, and Cd: $0.068 \mathrm{mg} / \mathrm{kg}$; Teluk Jakarta = Hg: $11.7 \mathrm{mg} / \mathrm{kg}, \mathrm{Pb}: 29.4 \mathrm{mg} / \mathrm{kg}$, and Cd: $0.42 \mathrm{mg} / \mathrm{kg}$; Brebes = Hg: $0.01 \mathrm{mg} / \mathrm{kg}, \mathrm{Pb}: 3.52$ $\mathrm{mg} / \mathrm{kg}$, and Cd: $0.4 \mathrm{mg} / \mathrm{kg}$; and Cirebon $=\mathrm{Hg}: 0.01 \mathrm{mg} / \mathrm{kg}, \mathrm{Pb}: 2.66 \mathrm{mg} / \mathrm{kg}$, and Cd: $0.73 \mathrm{mg} / \mathrm{kg}$. These results indicate that only green mussels from Panimbang contain heavy metals below the thresholds allowed to be consumed by humans.

Keywords: green mussels, heavy metals, Java coastal.

\section{Pendahuluan}

Kerang hijau merupakan makanan penting sebagai sumber protein. Budidayanya tergolong murah dengan pertumbuhan yang cepat. Pemijahan kerang hijau umumnya dipicu oleh peningkatan suhu air dan ketersediaan makanan. Proses memijah pada kerang hijau dapat terjadi sepanjang tahun di wilayah tropis, sedangkan di negara beriklim sedang bersifat musiman, bisanya terjadi pada musim panas (Soon \& Ransangan, 2014).

Menurut data DJPB (2015), empat daerah dengan produsen kekerangan tertinggi sebagai hasil budidaya pada tahun 2015 adalah Kabupaten Cirebon (7.834,8 ton), Kabupaten Gresik (7.685 ton), Raja Ampat (7000 ton) dan Kota Tual $(4.765,27$ ton). Hasil wawancara dengan pembudidaya kerang di Kabupaten Cirebon, diketahui kerang dibudidayakan dengan bagan tancap dari bambu yang diberi tali sebagai media penempelan benih kerang, tanpa pemberian pakan. Lama pemeliharaan kerang hijau hingga ukuran konsumsi memerlukan waktu 6-7 bulan (Sudradjat, 2015).

Pencemaran air laut merupakan kendala utama bagi sebagian besar aktivitas budidaya. Nagarjuna et al. (2019) melaporakan bahwa larva udang lebih sensitif daripada bibit ikan dan kerang hijau terhadap toksisitas $\mathrm{Ni}$ (nikel). Kerang hijau relatif tahan karena adaptasi fisiologis dan morfologis. Beberapa penelitian menyebutkan bahwa kerang dapat berfungsi sebagai biofilter, hal ini diketahui melalui akumulasi logam berat yang tinggi pada daging kerang (Riani, 2009). Kemampuan kerang untuk berperan sebagai biofilter bahan organik, telah dilaporkan Retnosari et al. (2019).

Riani (2009) menyebutkan bahwa penyerapan logam berat pada kerang hijau berbeda pada setiap ukuran, kemampuan menyerap pada kerang hijau berukuran kecil lebih terukur lebih tinggi terutama untuk logam merkuri. Tantanasarit et al. (2013) melaporkan bahwa kerang hijau secara efektif menyerap nutrien (karbon $(\mathrm{C})$, nitrogen $(\mathrm{N})$ dan fosfor $(\mathrm{P})$ dari kolom air melalui mengkonsumsi fitoplankton. Hal ini menunjukkan bahwa kerang hijau dapat bertindak secara efektif sebagai biofilter.

Konsumsi kerang hijau menjadi berbahaya jika dibudidayakan di perairan yang tercemar. Haryati et al. (2013) menyebutkan bahwa kerang hijau (Perna viridis L.) dari Teluk Jakarta tidak layak dikonsumsi akibat pencemaran logam berat $(\mathrm{Hg}, \mathrm{Pb}, \mathrm{Cd})$.

Cemaran logam berat $\mathrm{Hg}, \mathrm{Pb}$ dan $\mathrm{Cd}$ pada kekerangan bila dikonsumsi akan menyebabkan keracunan. Keracunan $\mathrm{Hg}$ menyebabkan penyakit neurotoksik (LeCoultre, 2001; EPA, 2020). Keracunan $\mathrm{Pb}$ dapat berpengaruh pada hampir semua sistem organ manusia, anak dibawah usia enam tahun lebih rentan terhadap efek $\mathrm{Pb}$, juga keracunan timbal pada wanita hamil dapat berakibat serius pada janin (U.S. EPA, 2019). Organ paling terpengaruh terhadap keracunan $\mathrm{Pb}$ adalah sistem hematopoetik, sistem saraf pusat, sistem saraf tepi, dan ginjal (Endrinaldi, 2009). Keracunan $\mathrm{Pb}$ dapat mempengaruhi sistem peredaran darah, sistem saraf, sistem urinaria, sistem reproduksi, sistem endokrin, dan jantung (Artati, 2018). LeCoultre (2001) menyebutkan bahwa efek keracunan $\mathrm{Pb}$ menyebabkan penyakit paru-paru dan kerusakan saraf (neurotoksik). Keracunan $\mathrm{Pb}$ memiliki efek buruk pada perilaku dan mental perkembangan anak-anak berusia 2-4 tahun (Hou et al., 2013). Kashala-Abotnes et. al. (2016) melaporkan bahwa paparan timbal pada masa kanak-kanak mempengaruhi perkembangan saraf dan temperamen anak usia dini. Kadmium yang termakan akan menyebabkan mual, muntah, salivasi, diare dan kejang perut. Efek racun dari kadmium menyebabkan kerusakan pada paru, ginjal, hati dan tulang (Endrinaldi, 2009; LeCoultre, 2001 ).

Akuakultur menyumbang $47 \%$ dari total produksi perikanan dunia (FAO, 2018). Data pada tahun 2017 menunjukkan total produksi perikanan 
budidaya di Indonesia $59,9 \%$ berasal dari budidaya laut, 20,8\% dari budidaya air tawar dan $19,3 \%$ dari budidaya air payau (KKP, 2018). Pengembangan budidaya kekerangan di Indonesia, terutama di pantai utara Jawa masih terkendala pencemaran logam berat, sehingga tidak layak dikonsumsi. Penelitian ini dimaksudkan untuk pemantauan kandungan logam berat pada kerang hijau.

\section{Metodologi}

Penelitian ini menggunakan data primer dan sekunder. Pengumpulan data primer dilakukan melalui wawancara dan survey lapangan ke sentra-sentra budidaya kerang hijau di Cilincing Jakarta Utara, Brebes, Cirebon, dan Panimbang Banten. Dari setiap lokasi diambil sampel kerang hijau untuk dianalisis lebih lanjut di laboratorium. Pengumpulan data sekunder dilakukan melalui studi pustaka, laporan statistik dan sumber lainnya. Data dan informasi hasil dari pengumpulan data di lapangan kemudian dianalisis menggunakan analisis deskriptif.

\section{Pengambilan Sampel Kerang Hijau}

Pengambilan sampel kerang hijau dilaksanakan di empat lokasi yang berdekatan dengan lokasi budidaya di pesisir Desa Panimbangjaya Kecamatan Panimbang Kabupaten Pandeglang, Desa Kali Baru Kecamatan Cilincing Kota Jakarta Utara (Teluk Jakarta), Desa Karangdempel Kecamatan Losari Kabupaten Brebes dan Desa Karangreja Kecamatan Suranenggala Kabupaten Cirebon dari satu stasiun di pengepul (Gambar 1). Sampel yang diambil merupakan kerang ukuran konsumsi, dengan panjang 6-8 cm dan lebar $2,5 \mathrm{~cm}$. Jumlah sampel dari Brebes dan Panimbang 25-30 ekor, sedangkan dari Teluk Jakarta dan Suraneggala 5060 ekor. Tabel 1 menyajikan waktu pengambilan sampel di masing-masing lokasi.

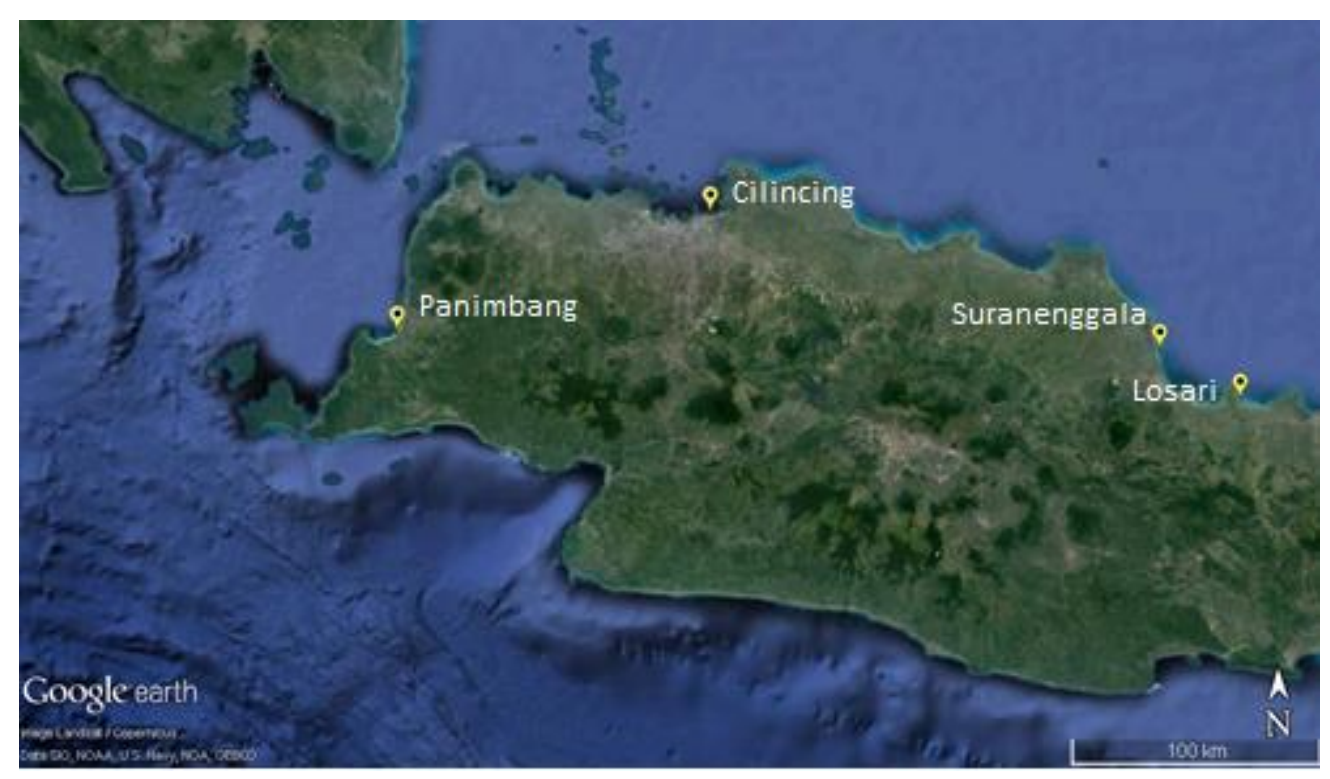

Gambar 1. Lokasi pengambilan sampel kerang hijau.

Figure 1. Sampling location of green mussels.

Tabel 1. Pengambilan sampel kerang hijau.

Table 1. Sampling locations of green mussels.

\begin{tabular}{lll}
\hline Locations & Sampling time & Shell size \\
\hline Suranenggala-Cirebon & March 2017 & \\
Losari-Brebes & September 2017 & Length 6-8 cm wide 2,5 cm \\
Cilincing-Jakarta Utara & April 2017 & Consumtion size \\
Panimbang-Pandeglang & April 2017 & \\
\hline
\end{tabular}




\section{Analisis Laboratorium}

Sampel dianalisis di laboratorium Proling, Fakultas Perikanan dan Ilmu Kelautan-IPB dan di Laboratorium Loka Pemerikasaan Penyakit Ikan dan Lingkungan Serang. Metode yang digunakan untuk mengetahui kandungan logam berat menggunakan teknik AAS (Atomic Absorption Spectrometry) metode APHA, ed.22, 2012, 3111B, 3030-E (daging kerang) dan AOAC (2012): 971.21 (tepung kerang). Sampel tidak dipisahkan antara bagian pencernaan dan daging kerang, semua digunakan sebagai bahan uji. Sampel dikomposit dari 25-29 ekor daging kerang segar disiapkan dalam bentuk kering oven sejumlah 50 gram. Pengukuran dilaksanakan pengulangan 3 kali.

\section{Hasil}

\section{Kadar Logam Berat Pada Kerang Hijau}

Hasil pengujian kandungan logam berat pada daging kerang hijau menunjukan bahwa di lokasi Teluk Jakarta, Suranenggala-Kabupaten Cirebon, dan Losari-Kabupaten Brebes sudah tidak layak untuk konsumsi karena kandungan timbal $(\mathrm{Pb})$ dan kadmium $(\mathrm{Cd})$ telah melebihi batas maksimum yang diijinkan berdasarkan Perka BPOM no 5 Tahun 2018. Bahkan untuk kerang hijau dari Teluk Jakarta kandungan merkurinya juga sangat tinggi $11,7 \mathrm{mg} / \mathrm{kg}$, sangat berbahaya jika dikonsumsi. Dari keempat lokasi tersebut terlihat bahwa kerang dari Teluk Jakarta paling tercemar. Hal ini bisa dipahami karena Jakarta merupakan kota terpadat dan juga terdapat banyak industri. Hasil pengujian kerang hijau dari Panimbang-Pandeglang terlihat masih layak untuk dikonsumsi.

Sementara itu untuk lokasi Cirebon dan Teluk Jakarta, pengujian dalam bentuk tepung, telah menurunkan kadar logam berat, raksa $(\mathrm{Hg})$, timbal $(\mathrm{Pb})$ dan kadmium $(\mathrm{Cd})$, dengan nilai masih pada ambang yang diijinkan untuk konsumsi sebagai bahan pangan. Kandungan logam berat pada daging dan tepung kerang di beberapa lokasi disajikan dalam Tabel 2 .

Tabel 2. Konsentrasi logam berat $(\mathrm{Hg}, \mathrm{Pb}, \mathrm{Cd})$ berat kering $(\mathrm{mg} / \mathrm{kg})$ pada kerang hijau.

Table 2. Heavy metal concentration $(\mathrm{Hg}, \mathrm{Pb}, \mathrm{Cd})$ dry weight $(\mathrm{mg} / \mathrm{kg})$ in green mussel.

\begin{tabular}{|c|c|c|c|c|c|c|}
\hline \multirow[t]{2}{*}{ (Locations) } & \multicolumn{2}{|c|}{$\mathrm{Hg} \mathrm{mg} / \mathrm{kg}$} & \multicolumn{2}{|c|}{$\mathrm{Pb} \mathrm{mg} / \mathrm{kg}$} & \multicolumn{2}{|c|}{$\mathrm{Cd} \mathrm{mg/kg}$} \\
\hline & Meat & Powder & Meat & Powder & Meat & Powder \\
\hline Suranenggala & 0,01 & 0,009 & 2,66 & $<0,5$ & 0,73 & 0,48 \\
\hline Losari & 0,01 & NA & 3,52 & NA & 0,4 & NA \\
\hline Teluk Jakarta & 11,7 & 0,02 & 29,4 & $<0,5$ & 0,42 & $<0,08$ \\
\hline Panimbang & $<0,22$ & NA & $\mathrm{ttd}$ & NA & 0,068 & NA \\
\hline $\begin{array}{l}\text { Max. threshold } \\
\text { BPOM*) }^{*}\end{array}$ & \multicolumn{2}{|c|}{0,5} & \multicolumn{2}{|c|}{0,2} & \multicolumn{2}{|c|}{0,1} \\
\hline
\end{tabular}

ttd: tidak terdeteksi/not detected

* Perka BPOM no 5 Tahun 2018, Sumber: data primer,

Berdasarkan dokumen hasil analisis laboratorium, pemeriksaan terhadap kadar logam berat $(\mathrm{Cd}, \mathrm{Pb}$ dan $\mathrm{Hg})$ dalam kerang hijau di Kabupaten Cirebon tahun 2016 (Dinas Kelautan dan Perikanan [DKP] Kabupaten Cirebon, 2016) menunjukan bahwa kandungan logam berat masih dibawah ambang batas dan masih layak dikonsumsi kecuali satu sampel dari Grogol kandungan $\mathrm{Cd}$ telah melebihi ambang batas BPOM, seperti yang disajikan dalam Tabel 3 . Metode pengujian logam berat dengan teknik AAS (Atomic Absorption Spectrometry). 
Tabel 3. Kandungan logam berat pada kerang hijau di Kabupaten Cirebon, Desember 2016 (DKP Kab. Cirebon, 2016).

Table 3. Heavy metal concentration in green mussel in Cirebon Regency, December 2016 (DKP Kab. Cirebon, 2016).

\begin{tabular}{cllll}
\hline Stasiun(Stations) & Lokasi (locations) & $\mathrm{Pb}(\mathrm{mg} / \mathrm{kg})$ & $\mathrm{Cd}(\mathrm{mg} / \mathrm{kg})$ & $\mathrm{Hg}(\mathrm{mg} / \mathrm{kg})$ \\
\hline 1 & Karang Reja, Suranenggala & $\mathrm{ttd}$ & 0,08 & $<0,22$ \\
2 & Karang Reja, Suranenggala & $\mathrm{ttd}$ & 0,008 & $<0,22$ \\
3 & Jatimerta, Gunung Jati & $\mathrm{ttd}$ & 0,03 & $<0,02$ \\
4 & Klayan, Gunung Jati & $\mathrm{ttd}$ & 0,06 & $<0.02$ \\
5 & Klayan, Gunung Jati & 0,06 & 0,06 & $<0,22$ \\
6 & Klayan, Gunung Jati & 0,02 & 0,09 & $<0,22$ \\
7 & Kalisapu, Gunungjati & $\mathrm{ttd}$ & 0,04 & $<0,22$ \\
8 & Kalisapu, Gunungjati & $\mathrm{ttd}$ & 0,03 & $<0,22$ \\
9 & Grogol, Gunung Jati & $\mathrm{ttd}$ & 0,05 & $<0,22$ \\
10 & Grogol, Gunung Jati & $\operatorname{ttd}$ & 0,22 & $<0,22$ \\
\hline & Batas Mak. BPOM* & 0,2 & 0,1 & 0,5 \\
\hline
\end{tabular}

ttd:tidak terdeteksi/not detected

\section{Pembahasan}

Telah banyak penelitian di Teluk Jakarta yang menunjukan bahwa kerang hijau hasil budidaya tidak layak konsumsi (Tabel 4). Apriadi (2005) menyampaikan bahwa kerang hijau yang diambil dari pantai Muara Kamal, Teluk Jakarta pada bulan September-Desember 2004, dengan menyakinkan telah tercemar logam berat $\mathrm{Pb}$ dan $\mathrm{Cr}$ dan tidak layak untuk dikonsumsi. Rata-rata kandungan $\mathrm{Pb}$ mencapai $40-45 \mathrm{mg} / \mathrm{kg}$ dan $\mathrm{Cr}$ mencapai 19,7-20,99 $\mathrm{mg} / \mathrm{kg}$ pada kerang hijau ukuran besar $(>6 \mathrm{~cm})$. Dalam penelitian tersebut kandungan $\mathrm{Hg}$ masih pada batas aman yaitu antara $0,009-0,05 \mathrm{mg} / \mathrm{kg}$.

Penelitian Winarno et al. (2009) di Muara Angke, Teluk Jakarta pada November 2005 kandungan $\mathrm{Hg}$ pada kerang hijau lebih tinggi $(0,8$ $\mathrm{mg} / \mathrm{kg}$ ) pada musim hujan dan tidak layak konsumsi. Pada Maret 2006, saat sudah masuk musim peralihan I kandungan $\mathrm{Hg}$ lebih rendah, yaitu $0,1 \mathrm{mg} / \mathrm{kg}$.
Penelitian Cordova et al. (2011) di Muara Angke, Teluk Jakarta menunjukan bahwa akumulasi logam berat tertinggi berada pada organ hepatopankreas dan kandungan logam berat pada sampel kerang yang diambil pada bagan tancap dengan usia tujuh bulan tidak layak konsumsi. Hal ini ditunjukan oleh kandungan $\mathrm{Hg}$ 138, $2 \mathrm{mg} / \mathrm{kg}, \mathrm{Pb} 33,66 \mathrm{mg} / \mathrm{kg}$ dan $\mathrm{Cd} 0,45$ $\mathrm{mg} / \mathrm{kg}$ yang jauh melebihi ambang maksimum yang diijinkan BPOM. Cordova et al. (2011) juga menegaskan bahwa kerang hijau di Teluk Jakarta lebih sesuai digunakan sebagai biofilter perairan laut yang tercemar dan bukan untuk dikonsumsi.

Hasil pengukuran $\mathrm{Pb}$ pada kerang hijau di perairan Cilincing, Teluk Jakarta telah melebih ambang batas untuk konsumsi. Hal ini dikuatkan oleh penelitian Barokah (2019) yang melaporkan kandungan $\mathrm{Pb} 0,29 \mathrm{~kg} / \mathrm{mg}$ pada tahun 2016, mengalami peningkatan pada April 2017 (29,4 $\mathrm{kg} / \mathrm{mg}$ ). Hasil penelitian Simbolon (2018) menunjukkan kandungan $\mathrm{Pb}$ pada bulan September-Desember 2017 adalah 7,43 kg/mg sampel. Sangat jelas terlihat kecenderungan peningkatan dari tahun 2016 ke tahun 2017. 
Andayani et al.

Tabel 4. Kandungan logam berat ( $\mathrm{Hg}, \mathrm{Pb}$ dan $\mathrm{Cd})$ pada kerang hijau penelitian lain.

Table 4. Heavy metal concentration $(\mathrm{Hg}, \mathrm{Pb}$ and $\mathrm{Cd})$ in green mussel in others research.

\begin{tabular}{|c|c|c|c|c|c|c|}
\hline Locations & $\begin{array}{l}\text { Size } \\
(\mathrm{cm}) \\
\text { age } \\
\text { (month) }\end{array}$ & $\begin{array}{c}\mathrm{Hg} \\
\mathrm{mg} / \mathrm{kg}\end{array}$ & $\begin{array}{c}\mathrm{Pb} \\
\mathrm{mg} / \mathrm{kg}\end{array}$ & $\begin{array}{c}\mathrm{Cd} \\
\mathrm{mg} / \mathrm{kg}\end{array}$ & $\begin{array}{l}\text { Sampling } \\
\text { time }\end{array}$ & Reference \\
\hline \multirow{3}{*}{$\begin{array}{l}\text { Muara } \\
\text { Kamal, Teluk } \\
\text { Jakarta }\end{array}$} & $>6 \mathrm{~cm}$ & 0,011 & 44,097 & NA & \multirow{3}{*}{$\begin{array}{l}\text { Sept - Dec } \\
2004\end{array}$} & \multirow{3}{*}{ Apriadi, 2005} \\
\hline & $4-6 \mathrm{~cm}$ & 0,016 & 34,89 & NA & & \\
\hline & $<4 \mathrm{~cm}$ & 0,006 & 12,83 & NA & & \\
\hline \multirow{2}{*}{$\begin{array}{l}\text { Muara } \\
\text { Angke, Teluk } \\
\text { Jakarta }\end{array}$} & $6-7 \mathrm{~cm}$ & 0,8 & NA & NA & Nov-2005 & \multirow[b]{2}{*}{ Winarno et al., 2009} \\
\hline & $6-7 \mathrm{~cm}$ & 0,1 & NA & NA & March 2006 & \\
\hline \multirow{4}{*}{$\begin{array}{l}\text { Muara } \\
\text { Angke, Teluk } \\
\text { Jakarta }\end{array}$} & $1-2 \mathrm{mo}$ & 35,47 & 17,13 & 0,07 & \multirow{4}{*}{$\begin{array}{l}\text { Nov 2010-Feb } \\
2011\end{array}$} & \multirow{4}{*}{ Cordova et al., 2011} \\
\hline & 3-4 mo & 205,73 & 33,51 & 0,078 & & \\
\hline & $5-6 \mathrm{mo}$ & 209,82 & 41,94 & 0,15 & & \\
\hline & $7 \mathrm{mo}$ & 138,2 & 33,66 & 0,45 & & \\
\hline $\begin{array}{l}\text { Cilincing, } \\
\text { Teluk Jakarta }\end{array}$ & NA & 0,25 & 0,29 & 0,11 & \multirow{3}{*}{ Oct-2016 } & \multirow{3}{*}{ Barokah et al., 2019} \\
\hline $\begin{array}{l}\text { Kalibaru, } \\
\text { Teluk Jakarta }\end{array}$ & NA & 0,26 & 0,21 & 0,13 & & \\
\hline $\begin{array}{l}\text { Muara } \\
\text { Kamal, Teluk } \\
\text { Jakarta }\end{array}$ & NA & 0,23 & 0,20 & 0,08 & & \\
\hline $\begin{array}{l}\text { Cilincing, } \\
\text { Teluk Jakarta }\end{array}$ & $4-7 \mathrm{~cm}$ & NA & 7,43 & NA & Sep-Dec 2017 & Simbolon, 2018 \\
\hline Kab. Cirebon & NA & NA & $\begin{array}{c}1,4- \\
2,1\end{array}$ & $0,3-0,5$ & Feb-Apr 2014 & Sukarno (2014) \\
\hline $\begin{array}{l}\text { Mundu, Kab. } \\
\text { Cirebon }\end{array}$ & NA & NA & 0,38 & $<0,4$ & Oct-Dec 2016 & Zahroh (2018) \\
\hline $\begin{array}{l}\text { Suranenggala, } \\
\text { Kab. Cirebon }\end{array}$ & NA & NA & $<0,23$ & $<0,4$ & & \\
\hline $\begin{array}{l}\text { Ngemboh, } \\
\text { Gresik }\end{array}$ & NA & NA & 0,41 & 0,09 & Jul-2013 & Eshmat et al., 2014 \\
\hline $\begin{array}{l}\text { Maximum } \\
\text { threshold }\end{array}$ & & 0,5 & 0,2 & 0,1 & & BPOM, 2018 \\
\hline
\end{tabular}

Penelitian Sukarno (2014) menunjukan bahwa kandungan $\mathrm{Pb}$ kerang hijau di Kabupaten Cirebon sudah melampaui ambang batas yang 140 diperbolehkan untuk dikonsumsi yaitu 1,4 - 2,1 $\mathrm{mg} / \mathrm{kg}$ dan $\mathrm{Cd}$ 0,3-0,5 mg/kg. Zahroh (2018) melaporkan kerang hijau yang diambil dari 
perairan Mundu, Kabupaten Cirebon kandungan $\mathrm{Pb}$ telah melebihi ambang batas yaitu $0,38 \mathrm{mg} / \mathrm{kg}$, sedangkan kerang hijau dari perairan Suranenggala mendekati batas aman untuk dikonsumsi. Penelitian Zahroh (2018) yang dilakukan pada tahun 2016 dibandingkan dengan penelitian ini yang dilaksanakan pada tahun 2017, menunjukkan kandungan $\mathrm{Pb}$ dan $\mathrm{Cd}$ pada kerang hijau dari Suranenggala telah mengalami peningkatan dan sudah tidak layak konsumsi.

Hasil analisis tingkat pencemaran di perairan Mundu dan Suranenggala Kabupaten Cirebon dengan metode STORET menunjukan bahwa perairan Mundu tercemar sedang sedangkan perairan Suranenggala tercemar berat (Zahroh, 2018). Padahal budidaya kerang hijau di Kabupaten Cirebon sebagian besar terkonsentrasi di Suranenggala, khusunya Desa Karangreja (Andayani dan Sugama, 2019).

Penelitian Eshmat et al. (2014) di perairan Ngemboh, Gresik menunjukan bahwa kandungan $\mathrm{Pb}$ telah melebihi ambang batas untuk konsumsi $(0,41 \mathrm{mg} / \mathrm{kg})$, kandungan $\mathrm{Pb}$ tertinggi dijumpai pada sampel di muara Sungai Ngemboh $(0,87$ $\mathrm{mg} / \mathrm{kg}$ ).

Hasil penelitan Jalius et al. (2008a) menyebutkan bahwa kandungan logam berat $\mathrm{Hg}$, $\mathrm{Pb}$ dan $\mathrm{Cd}$ dalam air di perairan Teluk Lada, Panimbang masih dibawah nilai maksimum, namun gonad kerang hijau yang berasal dari Teluk Lada telah mengandung logam $\mathrm{Pb} 0,018$ ppm dan Cd 0,006 ppm. Kandungan logam berat $\mathrm{Cd}$ dan $\mathrm{Pb}$ pada sedimen di perairan Teluk Lada masing-masing telah menunjukan 0,9 ppm dan $\mathrm{Pb}$ 2,3 ppm, diduga berasal dari limbah industri yang saat ini berkembang pesat serta limbah transportasi air dari kawasan industri CilegonMerak yang berada dekat dengan Teluk Lada, Panimbang (Jalius et al., 2008b). Erlania \& Radiarta (2011) melaporkan bahwa kandungan logam berat $\mathrm{Hg}$ masih di bawah nilai maksimum dan kandungan logam berat $\mathrm{Pb}$ dan $\mathrm{Cd}$ dalam air tidak terdeteksi di perairan Teluk Lada, Panimbang. Secara umum kualitas perairan di Teluk Lada masih baik ditinjau dari sisi konsentrasi logam berat $\mathrm{Hg}, \mathrm{Pb}$ dan $\mathrm{Cd}$.

Penelitian Prihatini (2013) di Muara Bama, Panimbang menunjukkan konsentrasi $\mathrm{Pb}, \mathrm{Cd}$, dan $\mathrm{Hg}$ baik pada kolom air dan subtrat telah melebihi ambang batas yang ditetapkan. Dalam penelitia tersebut juga dianalisis kandungan logam berat pada kerang darah Anadara granosa, dan menunjukkan kandungan $\mathrm{Pb}$ 0,125-0,85, $\mathrm{Cd}$ 0,125-0,425 dan $\mathrm{Hg} 0,02-0,30 \mathrm{mg} / \mathrm{kg}$. Penelitian tersebut juga menemukan kerang darah dengan kandungan $\mathrm{Pb}$ dan $\mathrm{Cd}$ yang telah melebihi ambang batas BPOM untuk konsumsi, dengan ukuran rata-rata panjang tubuh $1,87 \mathrm{~cm}$. Hasil penelitian kualitas periaran Teluk Lada dari tahun 2008 hingga 2013 menunjukkan kualitas perairan yang makin menurun, hal ini ditunjukan dengan meningkatnya konsentrasi logam berat $\mathrm{Pb}$ dan $\mathrm{Cd}$ yang terdeteksi melebihi ambang batas pada kerang darah. Namun demikian, hasil penelitian ini menunjukan kandungan $\mathrm{Hg}, \mathrm{Pb}$, dan $\mathrm{Cd}$ pada kerang hijau dari Teluk Lada masih dibawah ambang batas yang diijinkan untuk konsumsi. Hal ini menunjukan bahwa tingkat pencemaran di Teluk Lada tidak merata, tidak seperti pencemaran di Teluk Jakarta.

Kandungan logam berat $\mathrm{Hg}$ dalam kolom air di perairan Brebes masih di bawah batas maksimum yang ditentukan yaitu $0,018 \mathrm{mg} / \mathrm{l}$ (Siregar \& Murtini, 2008). Menurut Tewari et al. (2001) akumulasi konsentrasi logam berat yang terdapat pada kekerangan bergantung pada ukuran, jenis kelamin, habitat makanan, kondisi reproduksi, musim dan tingkat polusi.

U.S. EPA (1997) menyebutkan bahwa sumber pencemaran merkuri melalui pembuangan langsung ke air permukaan dan tanah dapat berasal dari aplikasi fungisida dan pestisida yang mengandung merkuri. Mukherjee et al. (2009) menyebutkan bahwa sumber pencemaran mercuri di India berasal dari pembakaran batubara, industri baja dan besi, pabrik metalurgi non besi, pabrik chlor-alkali, industri semen, sampah, pembakaran biomassa, lainnya termasuk didalamnya pabrik bata, instrumen dan termometer klinis.

Nordic Council of Ministers (2003) melaporkan bahwa pencemaran kadmium (Cd) ke tanah dan air antara lain bersumber dari sampah pertanian, pupuk, sampah kota, abu layang batubara, dan deposisi atmosfer, limbah rumah tangga, peleburan dan pemurnian logam bukan besi atau baja, serta pembuatan bahan kimia dan logam. Sumber pencemaran timbal $(\mathrm{Pb})$ di udara antara lain emisi dari bahan bakar minyak bumi yang dihasilkan oleh kegiatan transportasi dan industri, pembuatan baterai dan pembakaran batubara (Zhang et al., 2015).

\section{Kesimpulan dan Saran}

Sebagian besar kerang hijau yang diproduksi dari pantai utara Jawa telah tercemar logam berat dan tidak layak konsumsi. Sampel kerang hijau dari Suranenggala, Kabupaten Cirebon dan Losari, Kabupaten Brebes tidak layak 
konsumsi karena $\mathrm{Pb}$ dan $\mathrm{Cd}$ melebihi ambang batas. Kondisi paling buruk adalah kerang hijau dari Teluk Jakarta yang telah tercemar $\mathrm{Hg}, \mathrm{Pb}$, dan $\mathrm{Cd}$ dengan konsentrasi tinggi sehingga tidak layak dikonsumsi. Sedangkan kerang hijau dari Panimbang masih bisa dikonsumsi, namun perlu waspada karena kandungan $\mathrm{Cd}$ mendekati batas nilai ambang batas.

\section{Persantunan}

Penulis mengucapkan terima kasih dan penghargaan kepada Pusat Riset Perikanan dan Kelautan-KKP melalui pembiayaan DIPA TA 2017 serta kepada kabid budidaya beserta staf dinas perikanan dan kelautan Kabupaten Cirebon dan dinas perikanan dan kelautan Kabupaten Brebes yang telah membantu kegiatan lapangan penelitian ini.

\section{Daftar Pustaka}

Andayani, A., \& Sugama, K. (2019). Budidaya Kekerangan: Potensi dan Tantangan. Bunga Rampai: Potensi Sumber Daya Kelautan dan Perikanan di WPP NRI 712. Jakarta: AMaFRadpress-Badan Riset dan Sumber daya manusia Kelautan dan Perikanan, 163178

Apriadi, D. (2005). Kandungan logam berat $\mathrm{Hg}$, $\mathrm{Pb}$ dan $\mathrm{Cr}$ pada air, sedimen dan kerang hijau (perna viridis L.) di perairan Kamal Muara, Teluk Jakarta (Skripsi sarjana). Departemen Manajemen Sumberdaya Perairan, Fakultas Perikanan Dan Ilmu Kelautan Institut Pertanian Bogor, Bogor, Indonesia.

Artati. (2018). Analisis kadar Timbal (Pb) pada air yang melalui saluran pipa penyalur Perusahaan Daerah Air Minum (PDAM) Makassar. Jurnal Media Analis Kesehatan, 9(1), 47-55.

Badan Pengawas Obat Dan Makanan (BPOM). (2018). Peraturan Badan Pengawas Obat Dan Makanan Nomor 5 Tahun 2018 Tentang Batas Maksimum Cemaran Logam Berat Dalam Pangan Olahan. Jakarta, Indonesia: Author.

Barokah, G. R., Dwiyitno, \& Nugroho, I. (2019). Kontaminasi logam berat $(\mathrm{Hg}, \mathrm{Pb}$, dan $\mathrm{Cd})$ Dan batas aman konsumsi kerang hijau (Perna viridis) dari perairan teluk jakarta di musim penghujan. Jurnal Pascapanen dan
Bioteknologi Kelautan dan Perikanan, 14(2), 95-106.

Cordova, M.R., Zamani, N.P., \& Yulianda F. (2011). Akumulasi logam berat pada kerang hijau (Perna viridis) di Perairan Teluk Jakarta. Jurnal Moluska Indonesia, 2(1),18.

Dinas Kelautan dan Perikanan Kabupaten Cirebon. (2016). Laporan hasil investigasi kasus keracunan akibat konsumsi kerang hijau di Kabupaten Cirebon.Cirebon, Indonesia : Author.

[DJPB] Direktorat Jenderal Perikanan Budidaya. (2015). Produksi Komoditas Utama. Jakarta, Indonesia: Author.

Endrinaldi. (2009). Logam-logam Berat Pencemaran Lingkungan dan Efek Terhadap Manusia. Jurnal Kesehatan Masyarakat, 4(1),42-46.

Erlania \& Radiarta, I.N. (2011). Kondisi kualitas perairan di Teluk Lada Provinsi Banten untuk mendukung budidaya kerang hijau. Jurnal Riset Akuakultur, 6(3), 507-519.

Eshmat, M.E., Mahasri, G., \& Rahardja, B.S. (2014). Analisis kandungan logam berat Timbal $(\mathrm{Pb})$ dan Cadmium (Cd) pada kerang hijau (Perna Viridis L.) di perairan Ngemboh Kabupaten Gresik Jawa Timur. Jurnal Ilmiah Perikanan dan Kelautan, 6(1), 101-108.

FAO. (2018). The State of World Fisheries and Aquaculture 2018 - Meeting the sustainable development goals. Rome. Licence: CC BY-NC-SA 3.0 IGO.

Haryati, S., Sanim, B., Riani, E., Ardianto, L \& Sutrisno, D. (2013). Valuasi ekonomi dampak pencemaran dan analisis kebijakan pengendalian pencemaran di teluk jakarta. Globe, 15(2), 185-190.

Hou, S., Yuan, L., Jin, P., Ding, B. , Qin, N., Li, L., Liu, X., Wu Z., Zhao, G., \& Deng, Y. (2013). A clinical study of the effects of lead poisoning on the intelligence and neurobehavioral abilities of children. Theoretical Biology and Medical Modelling, 10(13), 1-9.

Jalius, Setiyanto, D.D., Sumantadinata, K., Riani, E., \& Ernawati, Y. (2008a). Bioakumulasi logam berat dan pengaruhnya terhadap oogenesis kerang hijau (Perna viridis). Jurnal Riset Akuakultur, 3(1), 43-52.

Jalius, Setiyanto, D. D., Sumantadinata, K., Riani, E., \& Ernawati, Y. (2008b). Akumulasi logam berat dan pengaruhnya terhadap spermatogenesis kerang hijau (Perna 
viridis). Jurnal Ilmu-Ilmu Perairan dan Perikanan Indonesia, 15(1), 77-83.

Kashala-Abotnes, E., Mumbere, P. P., Mishika, J. M., Ndjukendi, A. O., Mpaka, D. B., Bumoko, M. G., Kayembe, T. K., TshalaKatumbay, D., Kazadi, T. K., \& Okitundu, D. L. (2016). Lead exposure and early child neurodevelopment among children 12-24 months in Kinshasa, the Democratic Republic of Congo. European child \& adolescent psychiatry, 25(12), 1361-1367. https://doi.org/10.1007/s00787-016-0860-3

Kementerian Kelautan dan Periaknan [KKP]. (2018). Produktivitas perikanan indonesia. Naskah disajikan dalam forum merdeka barat 9 kementerian komunikasi dan informatika, Jakarta, 19 Januari 2018.

LeCoultre, T.D. (2001). Meta analysis and risk assesment of heavy metal (Master's thesis) Thenese Stae University USA, USA.

Mukherjee, A.B., Bhattacharya, P., Sarkar, A., \& Zevenhoven, R. (2009). Mercury emissions from industrial sources in India and its effects in the environment. in N. Pirrone and R. Mason (eds), Mercury fate and transport in the global atmosphere. Springer Science+Business Media, LLC 2009.

Nagarjuna, A., Karthikeyan, P., Marigoudar, S. R., \& Sharma, K.V. (2019). Effect of sublethal gradient concentrations of nickel on postlarvae of Penaeus monodon, Perna viridis and Terapon jarbua: Enzyme activities and histopathological changes. Chemosphere, 237, 124428.

https://doi.org/10.1037/pne0000225

Nordic Council of Ministers. (2003). Cadmium Review. Retrieved from https://www.who.int/ifcs/documents/forums /forum5/nmr_cadmium.pdf

Prihatini, W. (2013). Ekobiologi Kerang Bulu Anadara Antiquata di perairan tercemar logam berat. Jurnal Teknologi Pengelolaan Limbah (Journal of Waste Management Technology), 16(3), 1-10.

Retnosari, D., Rejeki, S., Susilowati, T., \& Ariyati, R.W. (2019). Laju filtrasi bahan organik oleh kerang hijau (Perna viridis) sebagai biofilter serta dampaknya terhadap pertumbuhan dan kelulushidupan udang windu (Penaeus monodon). Jurnal Sains Akuakultur Tropis, 3(1), 36-46.

Riani, E. (2009). Kerang Hijau (Perna viridis) ukuran kecil sebagai "Vacum Cleaner" limbah cair kawasan industri yang masuk ke dalam Perairan Teluk Jakarta. Jurnal Alami, 14(3), 24-30.

Simbolon, A.R. (2018). Analisis risiko kesehatan pencemaran Timbal $(\mathrm{Pb})$ pada kerang hijau (Perna viridis) di Perairan Cilincing Pesisir DKI Jakarta. Oseanologi dan Limnologi di Indonesia, 3(3), 197-208.

Siregar, T.H., \& Murtini, J.T. (2008). Kandungan logam berat pada beberapa lokasi perairan Indonesia pada tahun 2001 sampai dengan 2005. Squalen, 3(1), 7-15.

Soon, T. K. \& Ransangan, J. (2014). A review of feeding behavior, growth, reproduction and aquaculture site selection for green-lipped mussel, Perna viridis. Advances in Bioscience and Biotechnology, 5, 462-469.

Sudradjat, A. (2015). Budidaya 26 Komoditas Laut Unggul. Jakarta: Penebar Swadaya.

Sukarno, R. (2014). Penentuan kadar timbal dan cadmium dalam kerang hijau (Perna viridis L) hasil budidaya perikanan di Kabupaten Cirebon (Laporan tugas akhir diploma). Program Keahlian Analisis Kimia Program Diploma Institut Pertanian Bogor, Bogor, Indonesia.

Tantanasarit, C., Babel, S., Englande, A.J., \& Meksumpun, S. (2013). Influence of size and density on filtration rate modeling and nutrient uptake by green mussel (Perna viridis). Marine Pollution Bulletin, 68(1-2), 38-45.

Tewari, A. Joshi, H.V., Raghunathan, C., Sravan Kumar, V.G., \& Khambhaty, Y. (2001). Effect of heavy metal pollution on growth, carotenoid content and bacterial flora in the gut of Perna viridis (L.) in in situ condition. Current Science, 81(7), 819-828.

U.S. Environmental Protection Agency (U.S. EPA). (2020). Health Effects of Exposures to Mercury. Diakses dari https://www.epa.gov/mercury/healtheffects-exposures-mercury

U.S. Environmental Protection Agency (U.S. EPA). (2019). Learn about Lead. Diakses dari https://www.epa.gov/lead/learn-aboutlead\#effects

U.S. Environmental Protection Agency [U.S. EPA]. (1979). Status Assessment of Toxic Chemical: Cadmium. Cincinnati, Ohio.

U.S. Environmental Protection Agency [U.S. EPA]. (1997). Volume II: An Inventory of Anthropogenic Mercury Emissions in the United State (EPA-452/R-97-004). Mercury Study Report to Congress. 
Andayani et al.

Winarno, E. K., Andayani,W., \& Sumartono, A. (2009). Metil merkuri dalam kerang hijau (Mytilus viridis L.) dari pasar pelelangan ikan muara angke: sebelum dan setelah pemasakan. Indonesian Journal of Chemistry, 9(1), 77-83.

Zahroh, A. (2018). Kandungan Logam Berat (Pb dan Cd) Pada Air, Sedimen dan Kerang Hijau (Perna viridis) di Perairan Kabupaten Cirebon (Tesis master). Program Studi Pengelolaan Sumberdaya Alam dan
Lingkungan IPB, Bogor, Indonesia.

Zhang, R., Wilson, V.L., Hou, A. \& Meng, G. (2015). Source of lead pollution, its influence on public health and the countermeasures. International Journal of Health, Animal Science and Food safety, 2(1), 18-31. 